\title{
THe CASE For BROADENING \\ THE AMBIT OF RESTRAINT OF TRADE AND FOR FOCUSING ON REASONABLENESS
}

\author{
CONNOR BILDFELL ${ }^{*}$
}

\begin{abstract}
The jurisprudence in the area of restraint of trade reveals inconsistencies concerning what falls within the ambit of a restraint of trade. In addition, the modern employment relationship is of a radically different nature than the employment relationships of the past. This article reviews the historical approach and discusses some recent Canadian jurisprudence on restraint of trade. In light of changes to the employment landscape, this article proposes modifications to the court's characterization of "restraining" provisions and directs more emphasis towards reasonableness and the interest-balancing process. It concludes with an application of the proposed test for an unreasonable restraint of trade and a defence of the proposed alterations.
\end{abstract}

\section{TABLE OF CONTENTS}

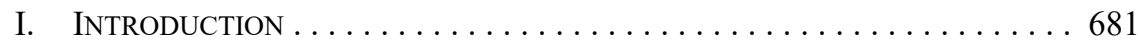

II. What Constitutes a Restraint OF TRADE? . . . . . . . . . . . 682

III. WHAT HAVE THE COURTS SAID

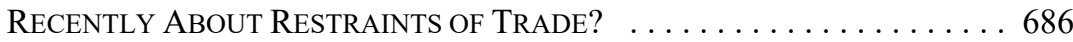

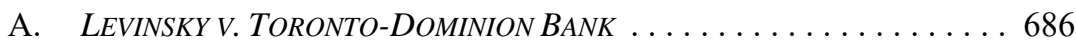

B. RHEBERGEN V. CRESTON VETERINARY CLINIC LTD. . . . . . . . . . 690

IV. HOW WOUlD BROADENING THE AMBit OF "RESTRAINT

OF TRADE" AND FOCUSING ON "REASONABLENESS"

OfFER A USEFul PeRsPeCtive IN THE EMPLOYMENT CONTEXT? . . . . . 693

A. Discussion of THE Proposed APPROACH $\ldots \ldots \ldots \ldots \ldots 63$

B. Moving Beyond "Traditional” Provisions $\ldots \ldots \ldots \ldots 696$

C. BALANCING INTERESTS THROUGH REASONABLENESS . . . . . . . . . 699

D. CRitiques of THE PROPOSED APPROACH $\ldots \ldots \ldots \ldots \ldots \ldots . \ldots 2$

V. How Might THE PRoposed REFocusing OF THE RESTRAint OF

TRADE DOCTRINE MODIFY THE APPROACH IN LEVINSKY? . . . . . . . . . . . 704

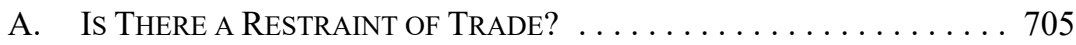

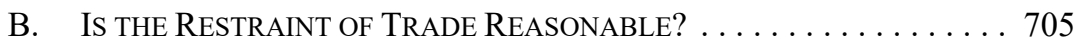

VI. CONCLUSION ............................... 706

\section{INTRODUCTION}

Several recent decisions have grappled with the issue of what constitutes a restraint of trade in the employment law context. The jurisprudence in this area reveals inconsistencies and confusion concerning what precisely constitutes a restraint of trade. In response to this murkiness in the law, this article proposes analytical modifications that place less emphasis on the court's characterization of potentially restraining provisions and directs more emphasis towards the assessment of reasonableness and the interest-balancing process. I will

JD candidate (2016), Peter A Allard School of Law, University of British Columbia. Thank you to the anonymous peer reviewers and to the editorial staff at the Alberta Law Review for their insightful comments and diligent work. All mistakes are my own. 
argue that the courts should be more willing to recognize provisions that may impair an employee's right or ability to seek alternative employment as restraints of trade, and that the heavy lifting should take place at the reasonableness stage.

Part II provides an overview of the legal landscape concerning restraints of trade. This article then transitions, in Part III, to taking a deeper look at two significant Canadian cases released recently: Levinsky v. Toronto-Dominion Bank ${ }^{1}$ and Rhebergen v. Creston Veterinary Clinic Ltd. ${ }^{2}$ These cases suggest that several aspects of this area of law are in need of reexamination. Part IV proposes that the courts should "lower the threshold" preceding the reasonableness inquiry in the employment contract context. Part IV also discusses the application of the restraint of trade doctrine beyond the more traditional restrictive covenants and addresses potential criticisms of this model. Part V illustrates how the refocused inquiry would apply to Levinsky. Part VI is a brief conclusion.

\section{What Constitutes a Restraint OF Trade?}

The common law has, over the centuries, ${ }^{3}$ developed distinct categories of public policy that may render a contract or contractual provision illegal. ${ }^{4}$ Restraint of trade is one branch of illegality that arises with considerable frequency. ${ }^{5}$ Historically, the common law took a strict, knee-jerk response to restraints of trade. ${ }^{6}$ This hostility is embodied in Nordenfelt $v$. Maxim Nordenfelt Guns \& Ammunition Co., in which Lord Macnaughten noted that "[i]n the age of Queen Elizabeth all restraints of trade, whatever they were, general or partial, were thought to be contrary to public policy, and therefore void." ${ }^{, 7}$ However, courts gradually adopted the view that certain restraints of trade are justifiable where there is a legitimate reason for them, though restrictive covenants are presumed to be unenforceable. ${ }^{8}$

2013 ONSC 5657, 117 OR (3d) 106 [Levinsky].

2014 BCCA 97, 372 DLR (4th) 191 [Rhebergen CA].

The common law's hostility towards agreements in restraint of trade emerged in the late sixteenth century, at which time the courts found such agreements to be stifling to the rapidly evolving British economy. See William Letwin, Law and Economic Policy in America: The Evolution of the Sherman Antitrust Act (New York: Random House, 1965) at 19. See generally Michael J Trebilcock, The Common Law of Restraint of Trade: A Legal and Economic Analysis (Toronto: Carswell, 1986).

4 This is illegality in the sense of being contrary to public policy. The result - i.e., the effect on a contract or contractual provision - of a finding of illegality depends on the type of illegality. This article focuses on the definitional aspect and reasonableness of restraints of trade, and it does not address remedial aspects.

5 See Stephen F Gleave \& Hicks Morley, "Restraint of Trade in Employment Law in Ontario: Old Principles, New Challenges" (Paper delivered at the CACE 10th Annual Conference, 2013) [unpublished] at 1, online: <www.counseltoemployers.ca/Live/digitalAssets/0/727_Tab_7-5-3_Stephen_Gleave.pdf $>$.

$6 \quad$ See Bruce MacDougall, Introduction to Contracts, 2nd ed (Markham, Ont: LexisNexis Canada, 2012) at 248 .

[1894] AC 535 at 564 (HL) [footnote omitted].

See Mitchel v Reynolds (1711), 1 P Wms 181, 24 ER 347 (Ch) [Mitchel], which abandoned the previous rule of per se invalidity established in Dyer's Case (1414), $2 \mathrm{Hen} \mathrm{V,} \mathrm{pl} \mathrm{26,} \mathrm{fol} 5$ (Ct Com Pl). Mitchel marked the beginning of the modern restraint of trade doctrine, which allows for the enforceability of certain restraints of trade when deemed reasonable. See also Shafron $v$ KRG Insurance Brokers (Western) Inc, 2009 SCC 6, [2009] 1 SCR 157, Rothstein J [Shafron] (finding that there is a "presumption that restrictive covenants are prima facie unenforceable" at para 17). 
To understand the issues concerning whether particular provisions are (or should be) enforceable, one must first address what constitutes a restraint of trade. ${ }^{9}$ A restrictive covenant, which may constitute a restraint of trade, is a term in a contract that attempts to protect the employer's "trade connections" with its customers, suppliers, and clients, as well as to protect the employer's confidential information and trade secrets against exploitation by one of its current or former employees. ${ }^{10} \mathrm{~A}$ restrictive covenant is unenforceable as being an unwarranted restraint of trade unless the party seeking to rely on the provision - typically the employer ${ }^{11}$ - can prove that it is reasonable. In making this determination, the court will have regard to several points. ${ }^{12}$ First, the covenant must be "reasonable between the parties and with reference to the public interest." ${ }^{\prime 13}$ Second, the balance is between the public interest in maintaining open competition and discouraging restraints on trade on the one hand, and on the other hand, the right of an employer to the protection of its trade secrets, confidential information and trade connections. ${ }^{14}$ Third, the validity of a restrictive covenant must be determined "upon an overall assessment, of the clause, the agreement within which it is found, and all of the surrounding circumstances." ${ }^{15}$ Fourth, three factors to consider when assessing the reasonableness ${ }^{16}$ of a clause are (1) did the employer have a proprietary interest entitled to protection; (2) are the temporal or spatial limits too broad; and (3) is the covenant overly broad in the activity it proscribes because it prohibits competition generally and not just solicitation of the employer's customers? ${ }^{17}$

The rationale is straightforward: "restraints of trade are contrary to public policy because they interfere with individual liberty of action and because the exercise of trade should be encouraged and should be free." 18 The restraint of trade doctrine seeks to unfetter the party subject to the covenant to allow him or her to enter contractual relations freely with third parties, hence advancing freedom of trade and the public interest. On its face, however, the

The argument advanced in this article could, in theory, be extended to include provisions limiting the employee's ability to take on outside work during the period of employment. That is, the rationale could extend to "anti-moonlighting" provisions prohibiting an employee from putting his or her abilities to their most productive use during the period of employment. These clauses have traditionally been seen as outside the doctrine of restraint of trade. For the sake of focusing the discussion, this article concentrates predominately on clauses pertaining to activity following the period of employment. Halsbury's Laws of Canada, 1st ed, Employment (Markham, Ont: LexisNexis Canada, 2011) at HEM253 "What constitutes a restrictive covenant" (2011 Reissue).

11 See Friesen v McKague (1992), 96 DLR (4th) 341 at 345 (Man CA) [Friesen] (asserting that the burden rests on the employer to prove all pre-requisites). But see JG Collins Insurance Agencies Ltd v Elsley, [1978] 2 SCR 916 at 928, Dickson J [Elsley] (finding that the burden of proof rests on the employee to demonstrate that the restrictive covenant is not in the public interest). The Court in Levinsky also placed the burden on the employee to demonstrate that the restraint is contrary to the public interest: supra note 1 at para 46.

12 These points are summarized in HL Staebler Co v Allan, 2008 ONCA 576, 92 OR (3d) 107 at paras 33-43.

Elsley, supra note 11 at 923.

Ibid.

Ibid at 924

Note that in Shafron, supra note 8, Justice Rothstein found that "[a]n ambiguous restrictive covenant will be prima facie unenforceable because the party seeking enforcement will be unable to demonstrate reasonableness in the face of an ambiguity": at para 27.

17 Elsley, supra note 11 at 925-26. As Adrian Brooks notes, non-solicitation clauses are more limited in that they restrain the former employee from seeking — or at times accepting — only the business of clients of the former employer. See Adrian Brooks, "The Limits of Competition: Restraint of Trade in the Context of Employment Contracts" (2001) 24:2 UNSWLJ 346 at 348. Non-solicitation clauses, however, may also be struck down as being unreasonable. Shafron, supra note 8 at para 16. 
restraint of trade doctrine impinges on freedom of contract to the extent that it deviates from the parties' agreement. ${ }^{19}$

Adrian Brooks asserts that there is an implied "duty of faithful service" in all employment contracts, which comprises three sub-duties: the duty of obedience, the duty to work with care and skill, and the duty of fidelity. ${ }^{20}$ This third implied duty may, in certain circumstances, give rise to a duty not to compete with the employer, but often the employer must formulate express terms in order to outline the contours of this duty and to attract the attention of the courts. ${ }^{21}$ The common law provides no implied restriction on the individual's freedom to compete after employment has ended. ${ }^{22}$

Part of the judiciary's interest in restrictive covenants in employment contracts stems from the context in which they arise. A central concern of the courts is the inherent imbalance of power between employer and employee. ${ }^{23}$ This imbalance of power may leave the employee at a significant economic disadvantage in negotiating the employment contract. ${ }^{24}$ As Lord Denning noted in M\&S Drapers $v$. Reynolds, if an employee wants to keep his employment

he has to sign the document which the employer puts before him; and he may do so without fully appreciating what it may involve. Moreover, if these covenants were given full force, they would tend to reduce his freedom to seek better conditions, even by asking for a rise in wages: because if he is not allowed to get work elsewhere, he is very much at the mercy of his employer. ${ }^{25}$

IGC Stratton, "Restraint of Trade During and on the Termination of a Contract of Employment" (1997) 12 Denning LJ 107 at 107. This observation assumes the contract was entered into freely and without a tainted bargaining process.

Brooks, supra note 17 at 346.

Ibid.

Ibid at 348. Brooks also notes that the rules of equity provide for the implied contractual duty of confidentiality, but the protection of goodwill requires an express provision. This article deals primarily with provisions seeking to protect goodwill.

23 It should be noted, however, that some scholars and theorists have argued that the modern employment landscape may not be subject to power imbalances to the same extent as the employment relationships of centuries past. See Gleave \& Morley, supra note 5 at 10:

A new breed of employee is emerging in the dominant industries such as financial services, technology and professional services. Subordinate relationships still dominate the interaction between employees and their employer; but in many sectors that now comprise our economy, employees function more like independent contractors. They do not just execute orders; they are intelligent, resourceful entrepreneurs who cooperate with their employer to run the business to maximize profits so that they can benefit through increased compensation or equity arrangements. See also Gérard Lyon-Caen, "The Evolution of Labour Law" in Labour Law in the Post-Industrial Era: Essays in Honour of Hugo Sinzheimer (Brookfield, Vt: Dartmouth, 1994) 93.

24 See Shafron, supra note 8 at para 23. The courts have drawn a distinction between contracts involving the sale of a business as a going concern and contracts of employment, with the latter presumably being more susceptible to power imbalances. See e.g. Allied Dunbar (Frank Weisinger) Ltd $v$ Weisinger, [1988] IRLR 60 at 64 (Ch) ("It is well settled that, in considering the validity of covenants in restraint of trade, very different principles apply where the covenant is taken for the protection of the goodwill of a business sold by the covenantor to the covenantee... The inclusion of such a covenant may be necessary to enable the covenantor to realise a proper price for the goodwill of his business; and by upholding the covenant the courts may well facilitate trade rather than fetter it.") See also Machtinger $v$ HOJ Industries Ltd, [1992] 1 SCR 986 at 1003, citing Katherine Swinton, "Contract Law and the Employment Relationship: The Proper Forum for Reform" in Barry J Reiter \& John Swan, eds, Studies in Contract Law (Toronto: Butterworths, 1980) 358 at 363 ("terms of the employment contract rarely result from an exercise of free bargaining power in the way that the paradigm commercial exchange between two traders does. Individual employees on the whole lack both the bargaining power and the information necessary to achieve more favourable contract provisions than those offered by the employers").

[1957] 1 WLR 9 at 18 (CA). 
This creates a paradox: to secure employment, the prospective employee must impair his or her ability to secure employment elsewhere and may even limit his or her prospects with the current prospective employer. These traditional covenants offer a more conspicuous means of restricting the employee's prospects, but what about modern provisions impacting intricate stock option plans, providing for "profit sharing" upon the employee's departure, creating fiduciary duties, or imposing financial penalties through a unanimous shareholders' agreement or through penalties triggered upon breaching an employment contract? These too, I argue, may constitute restraints of trade that may or may not be reasonable in the circumstances.

Moreover, as noted above, the court's concerns extend beyond the parties to the contract - they encompass broader societal implications. The result must strike a balance between, on the one hand, the need for competition and availability of talent and, on the other hand, the protection of private interests through freedom of contract. ${ }^{26}$ In Herbert Morris Ltd. v. Saxelby, Lord Parker of Waddington described the balancing process:

\begin{abstract}
It will be observed that in Lord Macnaghten's opinion [in Nordenfelt] two conditions must be fulfilled if the restraint is to be held valid. First, it must be reasonable in the interests of the contracting parties, and, secondly, it must be reasonable in the interests of the public. In the case of each condition he lays down a test of reasonableness. To be reasonable in the interests of the parties the restraint must afford adequate protection to the party in whose favour it is imposed; to be reasonable in the interests of the public it must be in no way injurious to the public. ${ }^{27}$
\end{abstract}

Thus, the finding that a particular provision constitutes a restraint of trade does not end the inquiry. The Court structured a two-step process: (1) Is there a restraint of trade? (2) If there is a restraint of trade, is it a reasonable one ${ }^{28}$ If the answer to the latter question is "no," the restraint will not be enforceable. ${ }^{29}$ The structure of analysis that I propose invites courts to take a broad view of the threshold question; however, the broadening of the threshold question governing what provisions are subjected to scrutiny must be counterbalanced by the analysis of the reasonableness of the particular provision. ${ }^{30}$

See MacDougall, supra note 6 at 249.

[1916] AC 688 at 707 (HL) [Herbert Morris].

See JD Heydon, The Restraint of Trade Doctrine (London: Butterworths, 1971) at 48.

See also Jostens Canada Ltd v Gendron (1993), 1 CCEL (2d) 275 (Ont Sup Ct J), Valin J ("[t]here is, in addition, a very basic question that should be asked when examining the reasonableness of a restrictive covenant in an employment contract. The fundamental question that should be addressed is: was the bargain fair?" at para 34).

30 This concept of outlining a broad scope that is "reined in" by considerations of proportionality or reasonableness is analogous to the analysis to which freedom of expression claims are subjected under the Canadian Charter of Rights and Freedoms, s 2(b), Part I of the Constitution Act, 1982, being Schedule B to the Canada Act 1982 (UK), 1982, c 11 [Charter]. The Court's landmark decision in Irwin Toy Ltd v Quebec (Attorney General), [1989] 1 SCR 927 at 967-78 outlined the two-stage framework used to ascertain the ambit of section 2(b). The first stage is to determine whether the impugned activity is protected by section 2(b). The large, liberal, and purposive interpretation applied to Charter rights brings nearly all expressive activity within the ambit of section 2(b). The second stage of the inquiry involves determining whether the government act infringes the freedom of expression. In most cases, the court finds without difficultly that the limitation infringes section $2(\mathrm{~b})$ - or this is conceded by the Crown - and the real discussion takes place at the section 1 justification stage: Patrick Macklem et al, eds, Canadian Constitutional Law, 4th ed (Toronto: Emond Montgomery, 2010) at 970. 


\section{What Have The Courts SaId Recently About Restraints of Trade?}

The courts have struggled to adopt a satisfactory approach to determining what constitutes a restraint of trade. I discuss below how the following two cases reveal the unsatisfactory state of the current jurisprudence in this area.

\section{A. LEVINSKY V. TORONTO-DOMINION BANK}

In the recent Ontario Superior Court of Justice case of Levinsky, ${ }^{31}$ Blair Levinsky, having received his LLB/MBA, began his career with TD Bank (the Bank) in 1999. Within four years, Levinsky's annual salary reached over $\$ 800,000$. Part of Levinsky's compensation took the form of the Bank's Long Term Compensation Plan (LTCP), which involved the granting of Restrictive Share Units (RSUs). Each year, Bank employees received a number of RSUs, which would mature into cash three years after being granted. However, if the employee to whom the RSUs were granted quit before the maturity date, the employee would not receive any payout for those RSUs.

In 2010, Levinsky tendered his resignation to the Bank, having decided to start up his own hedge fund. The Bank therefore denied Levinsky entitlement to RSUs granted to him in the previous three years, the cash value of which exceeded $\$ 1.6$ million. Levinsky argued that the contractual provision requiring forfeiture of the value of the RSUs was akin to a restrictive covenant. Such a covenant, he argued, was unreasonable and therefore unenforceable. ${ }^{32}$

In quickly dismissing Levinsky's claims of constructive dismissal and unconscionability, the Court took a keen interest in the sophistication of Levinsky, as well as the measures taken by the Bank to bring the forfeiture provisions to Levinsky's attention. The Court found that "Levinsky was a sophisticated individual, trained in both law and business" and that he was not a "contracting party laboring under an imbalance of bargaining power." 33 Moreover, the Bank circulated informational materials making clear the requirements for payments under the RSU scheme.

The Court then turned to whether the provision was a restraint of trade. The Court opined that whether a provision constitutes a restraint of trade is "determined not merely by the form of the clause, but by the effect of the clause in practice." 34 Hence, the traditional, direct covenant prohibiting any form of competition is not necessary for the court to find a particular provision to be a restraint of trade. This approach, termed the "functional" approach by Justice Lowry in Rhebergen CA, ${ }^{35}$ contrasts with the alternative "formalist" approach, which requires a more traditional direct prohibition to attract the court's attention

\footnotetext{
31 Supra note 1 . The facts are outlined in paras 1-32.
}

32 Levinsky argued that "The Bank has carefully crafted the RSUP so that it does not, on its face, appear to inhibit employee mobility or restrain trade; but that is its intended purpose": ibid at para 39.

33 Ibid at para 44. The Court takes direction from Titus $v$ William F Cooke Enterprises Inc, 2007 ONCA 573, 284 DLR (4th) 734 at paras 36-38.

$34 \quad$ Levinsky, ibid at para 50.

Supra note 2 at para 28. 
as a restraint of trade. ${ }^{36}$ The Court provided a hypothetical example whereby if a former employee were required to share profits on any new business acquired following his or her resignation, the clause would operate to cause the employee to refuse business he or she would otherwise take, thereby constituting a restraint of trade. ${ }^{37}$ However, as will be discussed, it is not clear that the Court discarded the formalist approach in a satisfactory manner.

Several cases noted in Levinsky underscore the current inconsistencies in the definition of restraint of trade. In Inglis,$^{38}$ the employment contract provided that the employee would receive commissions on business originating during the term of employment, even despite termination. However, if the employee became connected to or did work for any other life insurance company, commissions would be forfeited. The Ontario Court of Appeal held that this did not constitute a restraint of trade. ${ }^{39}$ The Court did, however, invalidate the relevant clause on other grounds, finding that it was overbroad in its scope.

The Ontario High Court of Justice in Furlong ${ }^{40}$ reached a decision that is difficult to square with Inglis. In Furlong, a settlement reached after termination required the former employer to provide a monthly retirement allowance to the former employee. However, if the former employee conducted himself in a matter detrimental to the former employer, that allowance would be ceased. The Court found this provision to be a restraint of trade and one that was unreasonable. ${ }^{41}$ The two cases may perhaps be distinguished on the basis that Furlong involved an allowance settled post-termination, whereas Inglis involved commissions stemming from business originating during the term of employment. Yet, this distinction is not entirely satisfactory — why should the courts treat these seemingly similar conditions in diametrically opposite ways?

Nortel Networks ${ }^{42}$ offers further evidence of the need to re-examine this area of law. In Nortel Networks, the provision stipulated that, if the employee accepted employment with a competitor within 12 months of exercising stock options granted by the former employer, any resulting profits would be paid to the former employer even if these options were exercised prior to resignation. The Ontario Superior Court of Justice held that a provision requiring the forgoing of a benefit as a result of engaging in competitive activities did not constitute a restraint of trade. ${ }^{43}$ Curiously, Nortel Networks appeared to adopt a preclusionH Ct J) [Furlong]; Colonial Broadcasting System Ltd v Russell (1964), 48 DLR (2d) 242 (Nfld SC); Taylor v McQuilkin (1968), 2 DLR (3d) 463 (Man QB). For examples of the "formalist" approach, see Inglis v Great-West Life Assurance Co, [1941] 4 DLR 242 (Ont CA) [Inglis]; Renaud v Graham, [2009] OJ No 597 (QL) (Sup Ct J (Div Ct)); Nortel Networks Corp v Jervis (2002), 18 CCEL (3d) 100 (Ont Sup Ct J) [Nortel Networks]; Webster v Excelsior Life Insurance Co (1984), 50 BCLR 381 (SC); Roy v Assumption Mutual Life Insurance Co (2000), 222 NBR (2d) 316 (QB); Woodward v Stelco Inc (1996), 20 CCEL (2d) 70 (Ont Ct J (Gen Div)).

Levinsky, supra note 1 at para 50.

Supra note 36.

Ibid at 245-46.

Supra note 36 .

Ibid at 698-99.

Supra note 36.

Ibid at paras 28-29. 
based approach. ${ }^{44}$ The Court found that the provision was not a restraint of trade as the former employee "did in fact pursue his profession with a competitor and [the clause] resulted in no economic disincentive for him from doing so." ${ }^{45}$ In my opinion, basing the determination of what constitutes a restraint of trade should not depend on whether the provision in fact dissuaded an employee from competing. The question at the definitional stage should be whether the provision may compromise, to any extent, the employee or the public's interests; whether the clause in fact has a preclusive effect is better considered at the reasonableness stage, at which point the goal is to balance interests in light of the circumstances. While it is true that what is reasonable for one employee may not be for another, a restraint is a restraint - this should be reflected at the definitional stage. Put another way, sanctions that offer little deterrence, in practice, are more likely to be reasonable, but they should not be seen as falling outside the scope of "restraint of trade."

After canvassing the case law in Canada and elsewhere concerning what constitutes a restraint of trade, the Court in Levinsky summarized that a clause that "operates to forfeit deferred compensation upon or following the cessation of the contract" must be assessed to determine whether the forfeiture is triggered by mere cessation of employment or whether it is triggered by the employee competing with the former employer. ${ }^{46}$ The former case, the Court asserted, is unlikely to be deemed a restraint of trade. ${ }^{47}$

Here, the Court draws a questionable distinction. Although Part IV of this article addresses the desirability of a distinction between competition-based clauses and cessation-ofemployment clauses, a brief note is required here. Despite endorsing a broad view of what might constitute a restraint of trade (i.e., form alone is not determinative), Levinsky took a narrow view of what it means to restrain trade. The Court implicitly posited that the emphasis is on restraint of trade affecting the employer. By focusing on whether the clause is triggered by competing in a particular industry, Levinsky oriented the inquiry around the interests of the former employer, rather than around the former employee's interest in mobility of labour or the public's interest in the provision of goods and services. In Levinsky, the Court found that, because the forfeiture was tied to Levinsky ceasing employment with the Bank, rather than engaging in post-employment competition with the Bank, the provision did not constitute a restraint of trade. The Court characterized the provision as a "loyalty incentive." $" 48$

The bright-line conceptual distinction between incentives and disincentives is untenable. "Incentives" include compensation — salary, bonuses, benefits, perks — and working conditions. "Disincentives" include post-employment conditions such as non-compete and non-solicitation provisions, forfeitures, and penalties. ${ }^{50}$ This categorization breaks down, however, when one considers that incentives such as stock options may vest or divest on

is approach is apparent in the Levinsky decisions as well ("[the impugned clause], in its practical operation, did not work to restrain Levinsky from leaving the Bank or restrain Levinsky's choice of postresignation commercial activities": supra note 1 at para 89).

Nortel Networks, supra note 36 at para 35.

Supra note 1 at para 81 .

Ibid.

Ibid at para 91 .

Michael Lindsay \& Katherine Santon, "No Poaching Allowed: Antitrust Issues in Labor Markets" (2012) 26:3 Antitrust 73 at 73.

Ibid. 
certain (perhaps quasi-punitive) conditions and that post-employment income may be structured to be a far greater deterrent against labour mobility than any simple non-compete clause.

The Court in Levinsky failed (or perhaps declined) to recognize that loyalty incentives, too, might be seen as constituting restraints of trade. Such provisions may compromise the mobility of labour and the provision of goods and services to the public. Had there been no forfeiture, Levinsky would be free to engage in an unfettered value analysis of, on the one hand, staying with the Bank and, on the other hand, pursuing other opportunities. Without the deterrent effect of being stripped of the valuable RSUs, Levinsky would be more inclined to pursue outside opportunities that may increase value to both Levinsky and society more broadly. On the other hand, the forgone value of the RSUs could simply be seen as composing part of the opportunity cost of pursuing an alternative endeavor and hence appropriately factored into the cost-benefit analysis. Which view one adopts is likely contingent on the extent to which there is a power imbalance between employer and employee. The notion of deterrence raises another concern: can we really decouple an impediment to leave from an impetus to arrive? That is, many contractual provisions both impose an obstacle to leaving and create an incentive to joining. To assert that one is permissible whereas the other is impermissible is to ignore that the two are intertwined: they are two sides of the same coin. An incentive used to acquire the employee initially that is subject to forfeiture connects both ends of the employment relationship.

The Court also noted the significance of whether or not the deferred compensation had vested in the employee. Where the deferred compensation had already vested prior to termination, a forfeiture may be regarded as a restraint of trade if it was "tied to posttermination commercial activity, not simply to the employee's continuation in service." ${ }^{\text {"51 }}$ As Gleave and Morley assert, "the loss of unvested payments upon resignation has never been accepted as sufficient to give rise to restraint of trade": no court in the common law world has accepted such a principle. ${ }^{52}$ However, this reasoning opens the door for employers to structure incentives creatively such that, although benefits are dependent on continuation of employment, the dominant effect is to deter employees from competing with the employer. This is not necessarily a questionable practice; the employer may simply be protecting its interests. Moreover, these provisions will often be reasonable. It is, however, a scenario that may give rise to disproportionate provisions. An alternative, more sweeping view is that the extinguishment or modification of either vested or non-vested benefits could, in the appropriate context, be treated as a restraint of trade, provided it constrains the individual's ability to freely pursue alternative employment. Accepting this rare possibility, however, would be a radical break from accepted case law. The conditions of vesting would then become an issue in the interest-balancing process, which is better attuned to taking into account the context and relative concerns of stakeholders. 


\section{B. RHEBERGEN V. CRESTON VETERINARY CLINIC LTD.}

We can contrast the approach adopted in Levinsky with that taken in the recent British Columbia Court of Appeal case of Rhebergen CA. ${ }^{53}$ These two cases are similar in the sense that neither involves a "traditional" restrictive covenant that prohibits the former employee from engaging in competition with the former employer. There are, however, significant differences that demand attention.

In the Rhebergen CA, Ms. Rhebergen, a young veterinarian looking to gain experience, entered into employment with the Creston Veterinary Clinic (CVC) - the defendant - for a three-year term. The Creston area, in which CVC's practice was based, had only two veterinarians within 100 miles. The employment agreement required Rhebergen to agree to a "non-competition" clause, which stipulated that Rhebergen would pay a certain amount to CVC if she "set up" a veterinary practice in Creston or within 25 miles of the defendant's premises. The penalty would vary depending on when Rhebergen set up a practice ${ }^{54}$ with the quantum being calculated by CVC based on previous experience, the cost of investment in hiring an associate, and the impact on the employer's goodwill.

After 14 months, Rhebergen indicated to CVC that she wished to resign; however, the employment contract precluded her from terminating the agreement before the end of the three-year term. CVC proceeded to terminate Rhebergen for cause. Rhebergen, hoping to open her own practice, sought a declaration that the non-compete clause was unenforceable.

At trial, the Supreme Court of British Columbia in Rhebergen v. Creston Veterinary Clinic Ltd. ${ }^{55}$ relied on Canaccord Capital Corp. v. Clough $^{56}$ in finding that the restraint of trade doctrine could be applied to a clause that does not directly prohibit competition. ${ }^{57}$ In Canaccord, the contractual provision required the employee to repay a portion of the training costs incurred by the employer in the event the employee commenced employment with a competitor within 39 months of the termination of the contract. The Supreme Court of British Columbia concluded that although the provisions did "not prohibit Mr. Clough from joining another investment dealer, the clause [did] operate in such a way as to limit competition. The principles relating to restraint of trade [were] applicable. ${ }^{, 58}$ In the result, the lower court in Rhebergen CA decided the case in favour of Rhebergen. The Court found the clause to be ambiguous - and hence unreasonable in light of Shafron — due to the use of the words

Supra note 2. The Rhebergen CA decision was released approximately six months after Levinsky. For further commentary on Rhebergen CA and Levinsky, see Valerie S Dixon \& Richard Truman, "Two Topics Relating to Restraint of Trade in Employment: Practical Alternatives to Restrictive Covenants and the Impact of Restrictive Covenants on Reasonable Notice" (Paper 3.2 delivered at the Employment Law Conference, Continuing Legal Education Society of British Columbia, May 2014) [unpublished], online: Miller Thomson LLP $<$ www.millerthomson.com/assets/files/article attachments2/VSDRET 2014-05_CLE.pdf>.

If Rhebergen "set up" a practice within one year of termination, she would pay $\$ 150,000$; within two years of termination, $\$ 120,000$; and within three years of termination, $\$ 90,000$ : Rhebergen CA, supra note 2 at para 3 .

2013 BCSC 115, 12 BLR (5th) 133 [Rhebergen SC].

(1999), 2000 CLLC 210-002 (BCSC) [Canaccord].

Rhebergen SC, supra note 55 at para 18.

Canaccord, supra note 56 at para 9 . 
"sets up a veterinary practice" and due to the conclusion that the monetary obligations constituted a penalty. ${ }^{59}$ The Court declared the clause to be unenforceable. ${ }^{60}$

On appeal, Justice Lowry wrote a dissenting judgment with which the majority agreed except on one issue: Justice Lowry's finding that the clause was ambiguous. ${ }^{61}$ A key difference between Rhebergen CA and Levinsky is that the clause in Rhebergen CA concerned the former employee competing with the former employer, whereas the clause in Levinsky took effect upon the simple cessation of employment by the employee. Both cases, however, involved clauses modifying the employee's financial circumstances, though in different ways. Justice Lowry noted that it is "by no means settled law" whether the mere imposition of a financial burden in pursuing alternative employment freely that one otherwise would not bear constitutes a restraint of trade. ${ }^{62}$

Here, against this background of conflicting authority, like the judge, I consider clause 11 of the associate agreement constitutes a restraint of trade. In my view, the functionalist approach established in English law is to be preferred as the legal basis for determining whether clauses that burden employees with financial consequences, whether by payment or forfeiture, they would not otherwise have for engaging in postemployment competition constitute a restraint on trade. In the words of Lord Wilberforce [in Stenhouse Australia Ltd $v$ Phillips], it is a matter of the effect of the clause in practice over its form. ${ }^{63}$

In Justice Lowry's view, it was unnecessary for the provision to prohibit the employee's ability to compete; it was sufficient that the effect of the clause was to compromise the employee's ability to compete. Thus, the provision constituted a restraint of trade. Justice Lowry drew a distinction between the "functional" approach, which looks to the effect of a clause, and the "formalist" approach, which requires the clause to be structured as a prohibition against competition in order to be deemed a restraint of trade. ${ }^{64}$ The latter approach, Justice Lowry asserted, would view "mere disincentives to post-employment competition" as insufficient to trigger the doctrine. ${ }^{65}$

As Justice Lowry noted, there has been significant uncertainty whether mere disincentives, rather than direct restrictions, tied to competitive activity are subject to the restraint of trade doctrine. Justice McLachlin (as she then was) in Burgess v. Industrial Frictions \& Supply Co. wrote, "Assuming (without deciding) that the doctrine of restraint of trade may apply to provisions other than direct restrictions on the right to work or trade, I am of the view that cl. 3 does not constitute an unreasonable restraint of trade." of Lord Slesser in Wyatt v. Kreglinger:

Rhebergen SC, supra note 55 at paras 22-26, 56.

Ibid at para 57.

Rhebergen CA, supra note 2 at para 71.

Ibid at paras $25-26$.

Ibid at para 42, citing Stenhouse Australia Ltd v Phillips, [1974] AC 391 at 402 (PC) [Stenhouse].

Rhebergen CA, ibid at para 28.

Ibid.

[1987] 4 WWR 182 at para 24 (BCCA). 
The public policy which has to be considered, the interest of the community, seems to be affected quite as much by an agreement that a person will give up a benefit which he would otherwise receive if he enters into a particular trade, as it is by a direct agreement by him not to enter into that trade. ${ }^{67}$

On the facts in Rhebergen CA, it is plausible that the provision served several legitimate goals of the employer. First, the employer sought to recoup its investment in the event the employee terminated the agreement prior to the maturity of the three-year term. ${ }^{68}$ This goal stands apart from concerns over the competitive activities. Second, the employer sought to offset the impact of the employee setting up as a competitor on the clinic's goodwill and business volume. ${ }^{69}$ These goals, which do not necessarily exhaust the goals the employer sought to achieve, are legitimate business interests that must be balanced against competing interests.

I generally agree with the approach taken in Rhebergen CA with respect to defining restraints of trade. Although the provision did not prohibit competitive activity, the effect was to compromise Rhebergen's ability to compete. Economic disincentives - in this case, taking the form of a monetary sanction varying in severity depending on the time since termination - act to restrain the individual's liberty of action because they impose a burden that otherwise would not be incurred by the employee. Furthermore, the judgment suggests that provisions placing a price tag on competing are more likely to be enforced than provisions barring competition outright. Is this a reasonable distinction? To my mind, this is a defensible position: although "price tag" provisions restrain labour mobility, they are less intrusive and a more proportionate response to balancing stakeholder interests.

However, the judgment could have gone further to discuss precisely what it means to "compromise" an employee's ability to compete. This term may aptly describe the effect of a broad swath of provisions in employment contracts. I would encourage the adoption of such a view, as it provides not only for symbolic recognition of the power imbalance between employers and employees, but it also allows courts to grapple with the balancing of interests at the "reasonableness" stage rather than to prematurely end the inquiry.

Justice Lowry also commented on the internal inconsistency in Levinsky. ${ }^{70}$ On the one hand, Levinsky endorsed Inglis and seemingly adopted the formalist approach by finding that clauses that did not preclude an employee "from going anywhere and doing anything he

$67 \quad[1933] 1 \mathrm{~KB} 793$ at 809 (CA).

68 See Hiebert $v$ Pacific Petroleums Ltd (1980), 109 DLR (3d) 137 at para 11 (Man QB) (acknowledging the legitimate interest of suppliers in recouping investments through an individually negotiated covenant).

69 The departing of an employee to join a competitor doubly harms the former employer. Not only does the former employer lose part of its return on investment in the employee, but it also aids a competitor by allowing it to reap the rewards of the investment made by the former employer. Alternatively, the employee may strike out on his or her own, as was the case in both Levinsky and Rhebergen CA. In that case, the former employer essentially underwrites the general skills training of the new competitor. See Norman D Bishara, "Covenants Not To Compete in a Knowledge Economy: Balancing Innovation from Employee Mobility Against Legal Protection for Human Capital Investment” (2006) 27:2 BJELL 287 at 301 .

Rhebergen CA, supra note 2 at para 38. 
chose to do" will not be considered a restraint of trade. ${ }^{71}$ On the other hand, Levinsky endorsed the effect-over-form approach, citing Stenhouse. ${ }^{72}$

In Rhebergen CA, the Court had an eye to the quantum of the penalty. Justice Lowry wrote,

While the unrecoverable costs to the clinic of Dr. Rhebergen leaving and competing within the three-year term of the agreement may vary depending when she was to leave, on the unchallenged evidence, properly understood, the amount to be paid could certainly not be said to be extravagant and unconscionable in comparison with the greatest costs to the clinic that could be proved. The judge's determination that it constituted a penalty was without evidentiary support. ${ }^{73}$

Despite the majority and minority agreeing that the clause constituted a restraint of trade, the two sides proceeded to disagree. The majority found the clause to be unambiguous and reasonable $;{ }^{74}$ the minority found the clause to be ambiguous and unreasonable. ${ }^{75}$ In the result, the clause was not declared unenforceable and Rhebergen's appeal was dismissed.

\title{
IV. How WOULd BRoAdENING THE AMBIT OF "RESTRAINT OF TrAdE" AND FOCUSING ON "REASONABLENESS" OFFER A USEFul Perspective in THE EMPloyment ConTeXt?
}

\section{A. Discussion of the Proposed APProACH}

\author{
The Supreme Court of Canada in Elsley held:
}

\begin{abstract}
A covenant in restraint of trade is enforceable only if it is reasonable between the parties and with reference to the public interest... [C]ompeting demands must be weighed. There is an important public interest in discouraging restraints on trade, and maintaining free and open competition unencumbered by the fetters of restrictive covenants. On the other hand, the courts have been disinclined to restrict the right to contract, particularly when that right has been exercised by knowledgeable persons of equal bargaining power. In assessing the opposing interests the word one finds repeated throughout the cases is the word "reasonable." The test of reasonableness can be applied, however, only in the peculiar circumstances of the particular case. $^{76}$
\end{abstract}

Looking to the rationales for the court's intervention in cases of restraint of trade, it is preferable to allow for a broad ambit of provisions to fall within the scrutiny of the restraint of trade doctrine. First, the individual has an interest in freely pursuing employment that is best suited to him or her. Considering the fundamental importance of employment in

Levinsky, supra note 1 at para 80. This follows the line of cases emanating from Inglis, supra note 36. See also Nortel Networks, supra note 36 (finding that a contractual provision requiring an employee to forego a benefit as a result of engaging in competitive activity was not a restraint of trade). Levinsky, supra note 1 at para 50, citing Stenhouse, supra note 63 at 402-403.

Rhebergen CA, supra note 2 at para 51.

Ibid at paras 71-74.

Ibid at para 69.

Elsley, supra note 11 at 923 
Canadian society ${ }^{77}$ it is all the more vital that the courts enforce a burden on the employer to take reasonable measures not to stifle the flourishing of individual employees, ${ }^{78}$ whether or not that employee is to remain employed by the employer. The courts should not risk restricting individual liberties. As a counterargument, might this be overly protective of employees and unduly burdensome to employers? Especially considering Gérard LyonCaen's observation that a new breed of employees who function more like independent contractors has emerged in the modern employment landscape, ${ }^{79}$ might lowering the threshold test promote an unfair balance in favour of employees? The employee presumably exercised his or her individual liberty and free will by agreeing to the contract — restraints and all - at the time of acceptance. Yet, such an argument overlooks the power imbalance inherent in many employment relationships ${ }^{80}$ and the lopsidedness in negotiating power may inevitably lead to exploitation or a "Hobson's choice" in which the employee must "take it or leave it." This effect may extend even to the "new breed" of employees described by Lyon-Caen, as it stifles their ability to adopt an independent contractor-like function. Moreover, the test for enforceability is not more stringent; it simply applies to a broader range of provisions.

Second, the public has an interest in the free movement of labour. ${ }^{81}$ The provision of goods and services (i.e., adequate supply) is contingent on the absence of unduly restrictive barriers to entry or restraints on trade; where employers can interfere in the free market by imposing disproportionate terms, the effect may be to confer a modest benefit on the employer while society suffers a significant detriment. There are inherent conflicts of interests in employment relationships. The court acts as the entity responsible, first, for ensuring that the interests of all parties are balanced and, second, for reaching a justifiable result that reconciles those interests. Allowing more cases to reach the interest-balancing stage would significantly improve the court's ability to serve the public interest and to weigh mobility of labour against other interests.

See Wallace v United Grain Growers Ltd, [1997] 3 SCR 701 (noting that the vulnerability of employees in the face of employers is "underscored by the level of importance which our society attaches to employment" and that "a person's employment is an essential component of his or her sense of identity, self-worth and emotional well-being" at para 93, Iacobucci J).

78 "Specific" human capital refers to the individual employee's earning potential and skills that are only useful in a particular work situation - i.e., it is non-transferable to third parties including other employers. "General" human capital refers to broadly useful skills that are valuable to third parties and are generally transferable. The employer, having trained the employee in general skills, may contend that it has a stake in the increased human capital possessed by the worker. This is seen as an "investment," and "because indentured servitude and owning another's labor are forbidden," non-compete clauses may be one of the only means by which an employer can retain its investment: Bishara, supra note 69 at 300-301. See also Gary S Becker, Human Capital: A Theoretical and Empirical Analysis, with Special Reference to Education, 3rd ed (Chicago: University of Chicago Press, 1993) at 33-35, 40-42. Lyon-Caen, supra note 23 at 96-97.

80 See Attwood v Lamont, [1920] 3 KB 571 at 581-82, 587 (CA) (in which Lord Justice Younger noted that freedom of contract evolved under the "laissez faire" school of economics. Such views are inapplicable, he noted, between employers and employees because the former developed a practice of putting into the agreement anything favourable to the employer.) But see Elsley, supra note 11 at 937 (asserting that freedom of contract is an important principle and must be given weight in determining whether the court will enforce the contract.)

81 This is not to say that the strength of the public interest in the free movement of labour does not vary. The public may have a greater interest in protecting the availability of certain goods or services due to geographical or economic circumstances, social expectations, etc. 
The threshold test is to establish that there is a provision that may restrain trade. There is, of course, no need to discuss the reasonableness of a restriction where no such restriction exists. The courts should abandon the formalist approach observed in Inglis entirely and should take a broad and generous functional approach that deems any provision that serves to compromise an employee's ability to compete or to restrain the mobility of labour to be a restraint of trade. Such a broad view could potentially encompass the type of provision in Levinsky that was triggered upon the cessation of employment because it could deter the employee from competing or, for that matter, simply taking his or her skills elsewhere. This definition would also encompass the financial disincentive imposed in Rhebergen CA, as it compromised the former employee's ability to compete.$^{82}$ Considerations of the trigger of the clause - for example, cessation of employment or setting up as a competitor — should not be determinative of the threshold characterization of the clause, though it is an important consideration when considering reasonableness.

The proposed broadening of the ambit of restraint of trade also recognizes and responds to a significant shift in the employment relationship itself. Employment relationships have evolved to become increasingly complex and increasingly transitory. Katherine Stone asserts that a "new psychological contract" between employees and employers has emerged. ${ }^{83}$ In contrast to the traditional implicit contract for lifetime employment and service to a single firm, the new implicit contract acknowledges that steady, long-term employment is less feasible in the modern context. ${ }^{84}$ Accordingly, workers show loyalty to a company in exchange for investments in general human capital and the freedom to take their skills elsewhere. The employee is sovereign. Restraints of trade, therefore, violate the new implicit contract by constraining the employee's mobility and free use of knowledge. ${ }^{85}$

In light of the progressively complex and transitory nature of employment relationships, it is reasonable to expect employers to turn to more creative means of ensuring the long-term loyalty of top talent. ${ }^{86}$ Direct restrictive covenants having effects triggered by the employee's competitive activity will constitute a smaller proportion of employer attempts to protect their investments in employees. ${ }^{87}$ This is especially the case considering that the blanket non-

This type of clause might be said to potentially hold an employee "hostage" in fear of incurring ruinous financial burdens.

Katherine VW Stone, "Knowledge at Work: Disputes Over the Ownership of Human Capital in the Changing Workplace" (2002) 34:3 Conn L Rev 721 at 729-31.

Ibid at 739-46.

Ibid.

See Brooks, supra note 17 at 380 :

in relation to post-employment restraints, the development of agency work and financial services has increased the importance of restraints for the protection of good will. Moreover, the nature of such businesses means that the clauses utilised are becoming increasingly complicated and that, in examining the reasonableness of a restraint's operation, the courts must undertake extremely complex analysis. Additionally, new types of restraint are gaining ground, and the question of reasonableness will involve not merely the breadth of limitation as to interest, time and geographical extent, but also the choice of the type of restraint that will protect the employer "adequately but no more than adequately."”

This trend has been recognized in jurisdictions outside of Canada as well. For example, the American Bar Association established Disciplinary Rule (DR) 2-108(A) of the Model Code, which, in the context of lawyer partnership contracts, not only prohibits direct non-compete agreements, but also prohibits indirect restraints such as forfeiture of benefits upon leaving to compete and financial penalties based on the clients the partner took with him or her. See American Bar Association, ABA Model Code of Professional Responsibility, online: $<$ www.americanbar.org/content/dam/aba/migrated/cpr/mrpc/mcpr. authcheckdam.pdf $>$; Sela Stroud, "Non-Compete Agreements: Weighing the Interests of Profession and Firm” (2002) 53:3 Ala L Rev 1023 at 1025. See e.g. Cohen v Lord, Day \& Lord, 75 NY (2d) 95 (1989) (invalidating, as violating DR 2-108(A), a provision of a law firm partnership agreement that imposed 
compete clause is essentially a "dead letter" in the eyes of the common law. ${ }^{88}$ Therefore, the judiciary's approach to defining restraints of trade must expand commensurately with the development of new means of constraining the employee's ability to take his or her skills elsewhere.

\section{B. Moving Beyond "Traditional" Provisions}

A notable upshot of opening up a broad ambit of "restraint of trade" in the definitional stage is that it brings the law into better alignment with the realities of modern working relationships and removes the need for "black and white" categorization. To illustrate, we can look to the Supreme Court of Canada's decision in Payette v. Guay Inc. ${ }^{89}$ While Payette was decided under the Civil Code of Quebec, ${ }^{90}$ the Court also applied common law principles in its analysis, rendering the case of interest nationally. Payette distinguishes between restrictive covenants negotiated in the commercial context from ones contained in the employment context where, as the Court emphasized, there is often unequal negotiating power. The result in Payette, which was to enforce the impugned restrictive covenant as reasonable, was welcome news for businesses seeking to rely on restrictive covenants that protect their interests; the judgment does not exhibit the typical hostility, as articulated in Nordenfelt, that courts have traditionally had towards restrictive covenants.

Guay Inc. (Guay) was a crane rental company. In 2004, it purchased assets belonging to Group Fortier, a competitor in the crane rental business. Group Fortier was owned and operated by Yannick Payette and his business partner. The two business partners agreed to work for Guay for six months following the sale in order to ensure a smooth transition. The contract of sale also supplied an option for continued employment beyond the six-month period. The key provisions under scrutiny stated that Payette would be bound by nonsolicitation and non-competition agreements for five years from the date at which his employment with Guay ceased.

Payette worked for Guay for over four years after the six-month transitional period before he was dismissed without cause. Seven months later, he began employment with a competitor of Guay. Shortly after, Guay lost seven of its most experienced employees to that competitor. The Quebec Superior Court granted Guay's motion for an interlocutory injunction until the hearing on the merits.

The key issue was whether the impugned restrictive covenant was linked to a contract for the sale of assets or to a contract of employment. Only if the clause was contained in a contract of employment would Article 2095 of the Civil Code of Quebec apply. Article 2095 stipulated that an employer may not avail himself of a non-competition clause if he has resiliated the contract without a serious reason. ${ }^{91}$ The Court emphasized the "cardinal rule" laid down in Shafron that "parties negotiating the sale of assets have greater freedom of

\footnotetext{
a financial disincentive on partners who terminated employment to compete with their former firm). See e.g. Atlantic Business Interiors Ltd v Hipson, 2005 NSCA 16, 230 NSR (2d) 76 at paras 36-37, 9798 [Atlantic Business Interiors] (affirming that full scale non-competition clauses will only be enforced in "exceptional cases").

2013 SCC 45, [2013] 3 SCR 95 [Payette].

CCQ.

Ibid, art 2095.
} 
contract than parties negotiating a contract of employment." 92 This follows from the observation that there is generally a power imbalance between the parties and an absence of a payment for goodwill in employment contract. ${ }^{93}$ This necessitates, at common law, a more rigourous and intense scrutiny of restrictive covenants in employment contracts.

Although a bright-line distinction between contracts for the sale of assets and contracts for employment is conceptually appealing, the Court in Payette acknowledged the "hybrid" nature of contracts such as the one under scrutiny. ${ }^{94}$ The Court divided on the question of whether the restrictive covenant arose in the contract of employment or only in the agreement for the sale of assets. ${ }^{95}$ Clearly the provision constituted a restrictive covenant, but the chief dilemma facing the Court was which legal test must apply, which in turn would be decided by a categorization of the clause.

Black and white decisions as to which test must apply are often necessary but are apt to create inconsistencies and questionable results when the issue falls in the gray. The Supreme Court of Canada concluded "Article 2089 C.C.Q., which imposes stricter rules and reverses the employee's burden of proving that a restrictive covenant in a contract of employment is unreasonable, does not apply in this case. ${ }^{, 96}$ One argument is that the legal test exhibits a formalistic approach in that it draws a bright-line distinction between restrictive covenants in the commercial context from those in the employment context. The modern employment landscape does not necessarily comprise solely those relationships that neatly fit into only one of these categories. There is little doubt that this distinction is accepted by the judiciary, but does the demarcation reflect reality? Having a legal test that emphasizes the reasonableness of the provision - rather than basing the legal test on the form of the provision - could allow the law to catch up with the complexity of modern employment relationships. This shift in emphasis would be consistent with the approach in Rhebergen $\mathrm{CA}$, which looks to the effect of the clause and its reasonableness rather than primarily to the form of the provision - form in this case being whether the clause is characterized as part of a sale of assets contract or an employment contract.

The Court made a significant observation that while an express and reasonable territorial limitation is necessary for a non-competition clause, such a limitation is not required for a non-solicitation clause to be enforceable. Justice Wagner, writing for a unanimous Court, wrote, "in the context of the modern economy, and in particular of new technologies, customers are no longer limited geographically, which means that territorial limitations in non-solicitation clauses have generally become obsolete." 97 The acknowledgement of the influence of new technologies and the realities of the modern economy suggest that the Court is duly taking note of the changing landscape of employment and client relationships. It remains to be seen whether a court might, in the right circumstances, arrive at the conclusion that the modern economy renders territorial restrictions obsolete in non-competition clauses. 
Turning to the scope of the proposed approach, Bury v. Bell Gouinlock Ltd. ${ }^{98}$ provides an illustration of how the restraint of trade doctrine could usefully be employed by litigants beyond the more traditional restrictive covenants. In Bury, Mr. Bury was a shareholder and employee of the respondent company. Bury left the employ of the respondent to work for another brokerage house in the same city. The shareholders of the respondent had a unanimous shareholders' agreement which provided that a shareholder who left the employ of the respondent was required to sell his or her shares to the company at prices and terms prescribed in the agreement. The alleged oppressive conduct was the company's invocation of a right under the shareholders' agreement to delay the mandatory sale of the departing employee's shares for twelve months. This tactic is essentially a backdoor method for restricting employees' ability to work for a competing company because stockbrokers cannot hold shares in two different stock brokerages at once. Since stockbrokers often take dividends as part of their remuneration package, the effect was to preclude Bury from working elsewhere for a full year. Bury filed for relief under section 247 of the Business Corporations Act, ${ }^{99}$ which, as the Ontario High Court of Justice noted, ${ }^{100}$ is substantially to the same effect as section 241 of the Canada Business Corporations Act. ${ }^{101}$ This provision, which Justice Eberle described as "far-reaching," 102 grants the court a broad discretion to make "any interim or final order it thinks fit" to relieve against oppression. ${ }^{103}$

The Court in Bury first grappled with the unusual circumstances of the application: "whether s. 247 of the Act may be utilized to give relief in face of a valid contract between the parties dealing with the very matters in issue." ${ }^{\text {"104 }}$ It does seem peculiar that the doctrine of oppression would be invoked when the activities giving rise to the litigation were also the subject matter of a written contract between the parties, the validity of which is unchallenged. ${ }^{105}$ After finding that the courts do have the power to set limits on the exercise of a power given by a shareholders' agreement, the Court turned to whether the decision of the company was oppressive to Bury. The Court noted that, due to stock exchange by-laws, "an individual cannot be a shareholder of two brokerage houses at the same time."106 Accordingly, the invocation by the company of the impugned provision "has the effect of preventing [Mr. Bury] from becoming a shareholder in his new employer and thus prevents him from obtaining dividend income or other income accruing only to a shareholder." 107 The Court found that "the deprivation to the applicant is sufficient to raise a prima facie case of

(1984), 12 DLR (4th) 451 (Ont H Ct J) [Bury].

SO 1982, c 4, s 247.

Bury, supra note 98 at 453.

RSC 1985, c C-44, s 241 [CBCA]. Subsection 241(2) reads as follows:

If, on an application under subsection (1), the court is satisfied that in respect of a corporation or any of its affiliates

(a) any act or omission of the corporation or any of its affiliates effects a result,

(b) the business or affairs of the corporation or any of its affiliates are or have been carried on or conducted in a manner, or

(c) the powers of the directors of the corporation or any of its affiliates are or have been exercised in a manner

that is oppressive or unfairly prejudicial to or that unfairly disregards the interests of any security holder, creditor, director or officer, the court may make an order to rectify the matters complained of.

102 Bury, supra note 98 at 453.

103 CBCA, supra note 101, s 241(3). This subsection also provides a lengthy list of non-exhaustive examples of orders the court may make.

Bury, supra note 98 at 452.

This is not to say that the Court erred in its conclusion that this could be the case.

Bury, supra note 98 at 453.

Ibid. 
oppression or unfairness." 108 The Court concluded that the company could not be permitted to rely on the impugned provision since it contravened section 247(2) of the Ontario Business Corporations Act.

The Court's reasoning in Bury bears a striking resemblance to the functional approach endorsed in Rhebergen CA: the Court is concerned less with the form of the provision than with its effect on the employee. This focus removes the prospect of clause enforceability being determined by the form or trigger of the provision.

A central theme of this article is that we should challenge the notion that it is only traditional restrictive covenants that should be subject to the restraint of trade doctrine. Although Bury does not contemplate that the impugned provision might constitute a restraint of trade or restrictive covenant, the case is a useful illustration of how a broad restraint of trade doctrine could be beneficial - at least to litigants. In essence, litigants could, if it suited their position, take the issue entirely out of the corporate context and instead import restraint of trade considerations. Analyzing Bury through the lens of restraint of trade, rather than through the oppression doctrine, removes the apparent peculiarity in invoking the oppression doctrine on the facts of Bury. Furthermore, in light of the broad discretion granted to the court under the CBCA to intervene as the court sees fit, it would be difficult to argue that invocation of the restraint of trade doctrine would be unduly intrusive to the agreement of the parties. This recognition that such a clause constitutes (or might in the abstract constitute) a restraint of trade allows the court to be more cognizant of and sensitive to the cases that defy the traditional categories of restraint of trade into which the courts place contractual provisions.

\section{BALANCING INTERESTS THROUGH REASONABLENESS}

Assuming the court finds a provision in restraint of trade, we can turn to the process of balancing the interests at hand and determining reasonableness. I will argue that this balancing of interests provides a robust framework upon which the court should carry out its heavy lifting. The court's assessment of what restraints of trade are "reasonable" bears a strong resemblance to the classic test set out in $R v$. Oakes, known as the Oakes test. ${ }^{109}$ Indeed, Pnina Alon-Shenker and Guy Davidov recently identified the implicit use of proportionality in the employment sphere. ${ }^{110}$ Proportionality, as a general principle of law, undergirds a significant body of judicial decision making, even when the concept is not invoked explicitly. ${ }^{111}$ As the authors noted, reasonableness, which is the standard applied by the courts in restraint of trade cases, is a vague legal concept; proportionality can be seen as a concretization of this more ambiguous notion. ${ }^{112}$ Alon-Shenker and Davidov argue that proportionality is a motivating principle in the exercise of balancing interests. ${ }^{113}$ Whether the

Ibid at 454 .

[1986] 1 SCR 103 [Oakes]. See generally Sujit Choudhry, "So What Is the Real Legacy of Oakes? Two Decades of Proportionality Analysis under the Canadian Charter's Section 1" (2006) 34:2 SCLR (2d) 501.

Pnina Alon-Shenker \& Guy Davidov, "Applying the Principle of Proportionality in Employment and Labour Law Contexts” (2013) 59:2 McGill LJ 375.

Guy Davidov, "The Principle of Proportionality in Labor Law and Its Impact on Precarious Workers" (2012) 34:1 Comp Lab L \& Pol'y J 63 at 65.

Alon-Shenker \& Davidov, supra note 110 at 395.

Ibid at 385-86. 
courts do (or should) apply a proportionality analysis akin to the Oakes test in the context of private law restraint of trade cases is beyond the scope of this article, but several of the concepts invoked - e.g., the balancing of interests, "minimal impairment," etc. — offer useful analogies. ${ }^{114}$

In analogizing the Oakes test to the court's treatment of restraints of trade, we can discern strong indications that the steps of the Oakes test implicitly inform what constitutes a reasonable restraint of trade. Before engaging in a proportionality test, the government must establish a pressing and substantial objective; this requirement is analogous to the court's requirement, in the restraint of trade context, that the employer have a legitimate proprietary or business interest. What constitutes an objective having sufficient substance to merit protection will "depend on the circumstances of each case and in particular the type of business of the employer and the role of the employee in the operation of that business." 115

As Stratton posits, we can deduce that the proprietary interests that the courts will protect will fall within two heads. ${ }^{116}$ First, there is the goodwill of the business, including trade connections with suppliers and customers. This interest will be more or less vulnerable to impairment depending on the extent to which the employee has access to customers and connections during employment. Second, there are the trade secrets and information requiring protection by the business. Notably, the courts have rejected the notion that an employer has a proprietary interest in preserving for itself the improvement in skill through the cultivation of the employee. ${ }^{117}$ John Heydon asserts that an "employee's personal skill can be used by him in competition with the employer even though he acquired it from the employer, even if it was very expensive, even if it was all the training the employee ever had." "118

Another element in determining what restraints of trade are reasonable is the extent to which the provision impairs the liberty of the former employee. Analogizing to the rational connection stage of Oakes, the employer must demonstrate why the particular provision is required to achieve its objective, which may be to protect sensitive information, maintain its clientele, ensure the loyalty of its employees, or advance other valid interests. When the employer attempts to achieve its objective through a restraint of trade - which, as noted above, may be one of the only mechanisms by which certain goals of the employer can be

The Supreme Court of Canada in Oakes interpreted section 1 of the Charter. Section 1 guarantees the rights and freedoms set out in the Charter "subject only to such reasonable limits prescribed by law as can be demonstrably justified in a free and democratic society." Put another way, section 1 allows the government to justify reasonable limitations on Charter rights and freedoms. The Court interpreted section 1 as requiring a proportionality test. This test, which follows the identification of a "pressing and substantial objective," comprises three steps: Oakes, supra note 109 at 138-40. First, the measure adopted by the government must be rationally connected to the objective. Second, in seeking to achieve the objective, the government must select a means which minimally impairs the right or freedom in question. Third, there must be a proportionality between the harms caused by the measure and the benefits of achieving the important objective. Dagenais $v$ Canadian Broadcasting Corp, [1994] 3 SCR 835 at 878 expanded upon this notion, requiring that the court balance the salutary effects against the deleterious effects of the legislation - that is, the court must not merely speak in abstract terms; the actual effects are relevant.

Stratton, supra note 19 at 118.

Ibid.

See Mason v Provident Clothing and Supply Co Ltd, [1913] AC 724 at 740-41 (HL); Herbert Morris, supra note 27 at 714 . 
reached - the court has an eye to whether there were other forms the provision could have taken that would be less intrusive on individual liberties. That is, analogizing to the minimal impairment stage of Oakes, the employer must demonstrate that the particular provision, in its form and effect, minimally impairs the rights of the employee to pursue alternative employment freely, while still achieving the employer's legitimate objective. ${ }^{119}$ Where the provision takes the form of a non-competition clause, this quasi minimal impairment test will invoke consideration of whether a non-solicitation clause would suffice to achieve the goal of the employer. ${ }^{120}$

Reasonableness includes consideration of the perspective of the employer and of the employee. Where the former employer is empowered to affect the former employee's ability to earn a livelihood after the termination of employment, it may be that the bargain reached was unreasonable from the employee's perspective. Reasonableness, however, is not restricted to the parties to the agreement; the court also examines whether the restriction is reasonable with respect to the public. ${ }^{121}$ The court should not lose sight of the fact that restraints of trade limit both individual freedom and the public's ability to access goods and services to which the individual may contribute through alternative employment. A compelling advantage of taking a broad view of the threshold question is that it allows courts to turn to a consideration of the public interest and thereby adopt a more contextual and balanced approach to enforcing such restraints.

Furthermore, the provision must be reasonable in terms of the activities it prohibits or sanctions, as well as the temporal and geographical scope of the restraint. ${ }^{122}$ Simply put, where the employer's private interests can be adequately achieved through means less restrictive to employees, such an alternative must be chosen. This concept is embodied in Friesen, in which the Manitoba Court of Appeal held that the onus is on the party seeking to uphold the provision that "the covenant is reasonable in that it goes no further than is necessary to protect the legitimate rights of an employer, and does not unduly restrain the employee." $" 123$

Typically, courts will find a blanket ban on post-employment competition as being disproportionately severe if a more limited restraint against soliciting the former employer's clients or exploiting confidential trade secrets and business information would adequately protect the employer's legitimate business interests. See e.g. Mason v Chem-Trend Limited Partnership, 2011 ONCA 344, 106 OR (3d) 72 at paras 20-31; Atlantic Business Interiors, supra note 88 at paras 36-37, 97-98 (affirming that full scale non-competition clauses will only be enforced in "exceptional cases").

120 See Elsley, supra note 11 at 926-28. Gleave and Morley highlight that courts are beginning to recognize that there are different types of solicitation and enforceability may depend on the form the nonsolicitation clause takes: supra note 5 at 6 .

121 The public interest aspect of the restraint of trade doctrine typically includes an examination of whether there is an adequate supply of goods or services in a particular industry or in a particular locale. Traditionally, very few post-employment non-competition covenants have been deemed unenforceable on the basis of the public interest. See Trebilcock, supra note 3 at 106.

122 See e.g. Elsley, supra note 11 at 924-26; Friesen, supra note 11 at 345-46; Lyons v Multari (2000), 50 OR (3d) 526 at paras 21-23. For a description of the rationale for requiring reasonableness with respect to the geographic area targeted by the impugned clause, see Spencer v Marchington, [1988] IRLR 392 (Ch) ("[t]he object of the rule of public policy against too wide an area is not primarily to protect the employee ... it is to protect the market open to prospective customers, to maximize the number of, in the present case, employment agencies available to them and to promote competition amongst them" at 396). In light of the importance of this rationale, the courts should be willing to take a broad approach to the scope of restraint of trade and should ensure that provisions affecting the public interest are subjected to a reasonableness inquiry. 
The issue of what is "unduly restraining" demands a contextual approach that takes strict account of the facts of the case. Such a process is best achieved not at the definitional stage of the restraint of trade doctrine, but rather at the reasonableness stage. This weighing process offers crucial significance in that a restraint of trade may have harmful or restrictive effects to a greater or lesser extent depending on the particular employment relationship. This consideration is akin to the cost-benefit analysis considered in Oakes. Consider, for example, that the deleterious effects of a provision requiring a wealthy investment banker to return a signing bonus may pale in comparison to the deleterious effects imposed on society by an employer prohibiting a formerly employed doctor from opening a private practice in an impoverished, rural area in need of medical services.

The foregoing demonstrates that the more robust inquiry of reasonableness — which takes a holistic account of the context in which the restraint arises as well as the competing interests at stake - should be the focal point of the court's assessment of restraints of trade. Accordingly, the "funnel" should be broadened to allow for the inclusion of a wide range of provisions within the scope of restraint of trade. This assertion, however, is not necessarily an invitation for the courts to strike down potentially restraining clauses with greater willingness; ${ }^{124}$ instead, it is a call to lower the threshold to reaching the assessment of reasonableness.

\section{Critiques of The Proposed ApProach}

The following critiques are not meant to be exhaustive; rather, they illustrate several compelling counterpoints. Perhaps the strongest critique of this article's position is the likely increase in litigation over the reasonableness of contractual provisions. With a wider ambit of potential application of the restraint of trade doctrine comes a concomitant increase in litigation and expenditure of the parties' and the court's resources. Moreover, the reasonableness inquiry is a lightning rod for criticism due to the judicial subjectivity it invites. The court must engage in a difficult assessment of the employer's commercial needs vis-à-vis the employee's and the public's interests. A related question is whether a court is engaging in an economic cost-benefit analysis that is arguably unsuitable for judicial evaluation. Judging whether a contract over-penalizes an employee for his or her posttermination activity — which is traditionally the subject matter of the restraint of trade doctrine - is one thing. But judging whether a contract simply makes changing jobs too unpleasant constitutes a much harder question for a judge to answer because it may turn on the standards of the industry and on balancing the cost to the employee of leaving the old employment against the benefit derived from the new employment. It may be preferable, therefore, for courts to outline strict, unambiguous rules as to what types and forms of provisions will be subject to the restraint of trade doctrine. In that vein, the formalist approach may provide the greatest degree of certainty and predictability. Further supporting this argument is the notion that the breadth and uncertainty of what may constitute a restraint of trade may in fact create an incentive for employees to breach the contract and to take a chance on the relevant provision being deemed an unreasonable restraint of trade. If we accept that a goal of contract law is to encourage the keeping of promises, this outcome is

124 Courts should be mindful that many of the employer's interests embodied in a restraint of trade provision are legitimate and worthy of protection. 
unfavourable. Breaches would also impose costs and inefficiencies that would not arise but for the expansive scope of restraint of trade.

On the other hand, while employers would be more vulnerable to being subjected to the restraint of trade doctrine, they can rest assured that any contractual provision must simply be reasonable. The standard of reasonableness remains unchanged and the shift in emphasis removes the inconsistencies that arise due to varying rates of success in avoiding scrutiny based on form. But might the scrutiny applied to benefits such as the stock options in Levinsky encourage employers to simply drop such benefits altogether? That result is unlikely. The more likely outcome is that employers will be more careful in drafting provisions revoking or altering the benefits to which the employees have (or may in the future) become entitled. ${ }^{125}$ Placing the focus on reasonableness of employment terms and refraining from ending the inquiry prematurely will discourage employers from overreaching while ensuring that provisions protecting legitimate business interests are given effect.

Should the judiciary only concern itself with clauses expressly targeting competitive activity, or would it be preferable to acknowledge that, in some circumstances, disincentives taking effect upon mere termination by the employee of the employment relationship may present an equally if not more compelling case for the restraint of trade doctrine? The case law, and Levinsky in particular, suggests that the aims of promoting individual freedom and the public interest in availability of goods and services are most offended by provisions targeting competitive activity. After all, these clauses are intuitively more controlling. Furthermore, the judiciary typically views penalties and disincentives that operate irrespective of competitive activities as delineating the contours of employment benefits rather than restricting freedom to compete. With rewards must come limits. One compelling argument follows: where these types of clauses do not in fact dissuade an employee from competing, how could they be defined as a restraint of trade? Moreover, if we were to characterize any limit on compensation or benefits as a restraint of trade, would this not catch nearly all terms setting the conditions of employee remuneration?

On the other hand, there is merit in recognizing that employee disincentives linked to termination, irrespective of competitive activity, can constitute restraints of trade. If this were not the case, the form of the provision would determine whether the clause could be subject to the restraint of trade doctrine. In practice, cessation-of-employment clauses may restrain the individual significantly. For example, an employee may face prohibitive penalties upon leaving a company and be practically precluded from setting up as a competitor. Even though he or she is free to do so in the sense that the contract may not penalize competitive activity, a sanction attached to mere departure may discourage or entirely dissuade an individual from freely pursuing his or her desired situation of employment. In addition, this scenario may equally harm the public interest by restricting the creation of market competition. The individual may be dissuaded from selecting alternative employment that offers greater utility

125 See Gleave \& Morley, supra note 5 at 2 (suggesting that "less is more" in this area of law, in the sense that adopting a more cautious approach maximizes the employer's chances of protecting the organization's legitimate interests.) Employers must be especially cautious and circumspect in drafting such provisions in light of the Supreme Court of Canada's decision in Shafron, supra note 8 (which found that "notional severance has no place in the construction of restrictive covenants in employment contracts" at para 37). 
to the individual and to society at large. While it is true that these provisions do not directly restrain the mobility of labour or the formation of competition, and employees are arguably free to take it or leave it and to seek employment elsewhere, the judiciary should be cautious of prematurely ending the inquiry as to whether these provisions unreasonably restrain trade.

Might the broad ambit I propose on the definition of restraint of trade lead the courts to deem the simple stoppage of salary upon the employee leaving an employer to be a restraint of trade? There are significant dangers in opening up the field of restraint of trade too broadly. However, the issue can be partly clarified by looking to Lord Diplock's judgment in Petrofina (Great Britain) Ltd. v. Martin, ${ }^{126}$ in which he described a contract in restraint of trade as "one in which a party (the covenantor) agrees with any other party (the covenantee) to restrict his liberty in the future to carry on trade with other persons."127 Moreover, Lord Wilberforce in Stenhouse asserted that the question was whether the clause is "likely to cause the employee to refuse business which otherwise he would take" or "diminish his prospects of employment." 128 The simple foregoing of salary payments due to the employee's cessation of the employment contract will not, in most circumstances, constitute an unreasonable restraint on his or her liberty to carry on trade in the future, and it may not necessarily have the effects identified by Lord Wilberforce in Stenhouse. It goes without saying that the cessation of salary payments is a reasonable response to an employee's termination of the employment contract. Hence, even if such a basic ramification of leaving an employer as the stemming of salary payment were deemed a restraint of trade, there would be little question as to its reasonableness.

\section{How Might the Proposed Refocusing of the Restraint of Trade Doctrine Modify The APPROACH IN LEVINSKY?}

I now turn to the application of the principles outlined above to Levinsky. This process will illustrate how the judiciary might refocus its analysis in cases involving restraints of trade to improve the clarity and cogency of its decisions. The core proposition motivating this brief discussion is that, by opening up a broad ambit to the term "restraint of trade," combined with performing the heavy lifting at the reasonableness stage, courts can expunge the inconsistencies apparent in the current jurisprudential landscape. Several concepts arising out of the Oakes test framework inform the consideration of reasonableness, but the drawing of analogies to these concepts should not be seen as importing all considerations brought to bear in constitutional cases. There are distinct differences in context that should not be overlooked. at 298-99 (HL) (in which Lord Reid stated that he "would not attempt to define the dividing line between contracts which are and contracts which are not in restraint of trade"). 


\section{A. Is There a Restraint OF Trade?}

The preliminary question should be seen as broad in scope, encompassing provisions that compromise the individual's ability to seek alternative employment. The matter should not be decided simply by asking whether the clause is linked to post-termination competitive activity. ${ }^{129}$ In Levinsky, by imposing a "loyalty incentive," the Bank also imposed a disloyalty disincentive, which could be seen as constituting a restraint of trade. Even though the provision did not directly preclude (or even sanction) Levinsky from obtaining employment elsewhere, the economic effect of his doing so could act as a restriction on the ability and freedom he would otherwise have to pursue employment elsewhere.

The counterargument to this position is compelling, however. Is it not true that Levinsky freely entered the employment relationship, agreed to the terms of the LTCP, and always had the option of forfeiting the value of the RSUs if he so wished? Indeed, at least theoretically, Levinsky will be a rational economic actor and will incur the cost of leaving when his benefit in doing so exceeds those costs. These points are persuasive, but the courts should address these crucial points not at the scope stage of the restraint of trade inquiry, but rather at the reasonableness analysis. The reason for this structure is that the concept of reasonableness is better attuned to balancing competing interests and factors that influence whether a given restraint can be upheld; the question of whether there is a restraint in the first place should be seen as broad in scope in order to avoid the inconsistency that has arisen over the functionalist versus formalist debate as to what exactly is a restraint of trade. It should be recalled that employers will frequently and rationally seek to limit the ability — in one way or another - of an employee to market his or her labour elsewhere; the key task is determining when such provisions can be upheld as reasonable.

\section{B. IS THE RESTRAINT OF TRADE REASONABLE?}

The Court asserted that the LTCP was structured as a loyalty incentive, and it is plausible that the employer's primary goal was to retain valuable employees rather than to restrict postemployment competition created by Levinsky. ${ }^{130}$ In light of the fact that Canada is increasingly becoming a knowledge economy, the human capital of a firm is a central source of value. Hence, there is little doubt that the interests the Bank seeks to protect - at least one of its primary objectives - are legitimate. The employer seeks to protect its competitive position, to retain key employees, and to protect its goodwill.

As is the case in the section 1 context, the minimal impairment stage applied mutatis mutandis to the employment law context serves as a focal point in the analysis. One highly significant factor in favour of upholding the provision in Levinsky as reasonable — if it even is a restraint - is the form it takes: the restriction does not impose direct prohibition on competing, nor is there even a general sanction on being employed elsewhere. The effect is to forfeit a yet-to-be-vested benefit, which was voluntarily provided by the Bank and will deem a provision that is triggered upon the employee leaving the employer to be a restraint of trade compared to one that is triggered upon competing in some form.

130 See Levinsky, supra note 1 at paras 9,12. Note that employers will generally be pursuing multiple goals concurrently, and this is likely the case in Levinsky. 
voluntarily accepted by Levinsky, in the event the employee ceased employment with the employer. The Bank chose not to impose more punitive measures such as a direct fine for ceasing employment or a demand for a share of profits earned through the former employee's employment with a competitor. Rather, the Bank sought to achieve its objective of advancing employee loyalty by offering a benefit subject to conditions, which was willingly accepted by the employee. This latter point is underscored by the fact that the employer went to great lengths to provide detailed information regarding the terms of the benefits guaranteed to employees. In addition, the clause in Levinsky called for the forfeiture of the value of the RSUs accumulated over the three years preceding the employee's cessation of the contract. Hence, only part of the employee's benefits were to be forfeited, which is a factor in favour of finding the provision to be reasonable. Whether the particular balance struck by the employer is defensible is arguable, but the result reached by the Court seems appropriate in light of the foregoing. ${ }^{131}$

Bearing in mind the increasing complexity of employment contracts and the proliferation of new types of restraints, courts must consider the alternative forms the provision could have taken. The argument that the employer did not pursue the least restrictive means possible is not tenable. Similar to considerations in the Oakes test, the test should be one of reasonable alternatives. A less restrictive option in Levinsky might have included a forfeiture of a lesser sum or, perhaps least restrictive of all, the shares granted to the employee might have been immune from forfeiture entirely. Yet, these options would not achieve adequately the goals of the employer. The court must have an eye to striking a just balance, and the context and circumstances of each case will be at the core of such a process.

In looking to the effect of the forfeiture clause in the Levinsky contract, the Court noted that the "evidence hardly suggests that [the forfeiture clause] operated, in practice, to limit [Levinsky's] range of post-resignation commercial activities." 132 This evidences an effectsbased approach that takes into consideration the practical effects of the clause in question, as well as the extent of its deleterious effects. The Court did not expressly look to the other side of the coin - that is, the salutary effects experienced by the Bank in terms of its success in retaining valuable talent more generally. Grappling with these aspects would improve the judicial inquiry and would further ground the analysis in a holistic approach to reasonableness.

\section{CONCLUSION}

The purpose of the foregoing analysis is to illustrate that several of the points raised by the courts at the threshold definitional stage can be transferred to the reasonableness stage with the result of greater consistency and favourable policy outcomes. Provisions akin to those in cases such as Levinsky, Rhebergen CA, Inglis, and Nortel Networks demand recognition of their potentially restrictive nature, though such provisions should not necessarily be unenforceable. I argue that the courts reached a just result in both Levinsky and Rhebergen CA, but the process by which the result was reached needs modification. 
The modern employment relationship is of a radically different nature than the relationships of centuries past. As a result, the classic non-compete agreement is being cast aside in favour of more creative contractual tools. The courts should expand the definition of "restraint of trade" to properly respond to this development. By avoiding prematurely ending the inquiry as to the enforceability of such provisions and by focusing on reasonableness, the judiciary would construct a more consistent and predictable treatment of clauses in restraint of trade. 
